\title{
Observations of Torpor-like Behavior in the Shrew, Sorex sinuosus
}

\author{
Czy Sorex sinuosus zapada w odrętwienie?
}

James R. NEWMAN \& Robert L. RUDD

\begin{abstract}
Newman J. R. \& Rudd R. L., 1978: Observation of torpor-like behavior in the shrew Sorex sinuosus. Acta theriol., 23, 30: 436-438 [With 1 Table \& 1 Fig.].

The occurrence of a torpor-like behavior was observed in Sorex sinuosus. During metabolic experiments animals become inactive, breathing rate slowed and oxygen consumption dropped 63 to $88 \%$ from the resting metab ic rates. On arousal, behavior and metabolic rates returned to normal.

[Environ. Sci. Engineer., Inc. P.O. Box 13454, Univ. Stat. Gainesville, Florida 32605 (JRN) and Dept. Zool., Univ. Calif., Davis, California 95616 (RLR)].
\end{abstract}

The high energy requirements of shrews are well documented ( $\mathrm{G}$ ębczyński, 1965; Voge 1, 1976). For animals of small size with high energy demands and fluctuating energy supplies daily torpor is commcn. This is especially true for insectivorous bats, heteromyid rodents, hummingbirds, swifts and goatsuckers (B a r t h o l o m e w, 1972). Shrews also fit into this category of animals where daily torpor might be expected (B a r tholom e w, 1972). To date no solid evidence has been reported to verify its occurrence in shrews.

During metabolic studies on Sorex sinuosus (N e w man \& R u dd, 1978) large numbers of shrews were maintained in the laboratory. On numerous occasions these animals appeared to go into a deep sleep or torpor. Activity ceased, the breathing rate slowed, and the animal appeared to be dying. Considerable stimulation was needed to arouse the

Table 1

Comparison of late summer resting metabolic rates of $S$. sinuosus with metabolic rates observed during periods of torpor-like behavior.

\begin{tabular}{|c|c|c|c|}
\hline \multirow{2}{*}{$\begin{array}{c}\text { No. of } \\
\text { Individuals }\end{array}$} & \multirow{2}{*}{$\begin{array}{l}\text { Body Weight } \\
\text { (grams) }\end{array}$} & \multicolumn{2}{|c|}{$\begin{array}{l}\text { Oxygen Consumption } \\
\left(\mathrm{cc} \mathrm{O}_{2} \mathrm{gm}^{-1} \mathrm{hr}^{-1}\right)\end{array}$} \\
\hline & & Resting ${ }^{1}$ & Torpor ${ }^{2}$ \\
\hline 22 & $5.4 \pm 0.7$ & $7.8 \pm 2.1$ & \\
\hline 1 & 7.8 & $10.4 \pm 4.0$ & $1.3 \pm 1.2(6)$ \\
\hline 1 & 5.4 & $6.4 \pm 0.9$ & $2.4 \pm 0.5$ \\
\hline
\end{tabular}

124 hour measurement.

2 Mean for period of observed torpor; () equals the number of $7.5 \mathrm{~min}$. measurements during torpor period.

animal. In fact the animal, during these deep sleeps, could be handled and even pushed over without immediately righting itself. After awckening, the animal acted normally with sharp and quick reflexes. On two occasions during metabolic experiments similar torpor-like behavior was observed. This behavior was associated with a dramatic decrease in mea- 
bolic rates. The metabolic rates measured during these periods were $63 \%$ and $88 \%$ lower than normally observed resting metabolic rates (Table 1 ). These periods of deep sleep lasted from a couple of minutes up to an hour in length (Fig.1). Knocking and tilting the metabolism chamber resulted in arousal and return to normal behavior and metabolic rates. In one case following initial arousal the shrew went back into torpor for several more minutes before returning to an active state (Fig. 1). In both of these instances food was available. The temperature of metabolism chambers was $20^{\circ} \mathrm{C}$.

No predictible torpid pattern was noted nor was torpor induced under fasting conditions. The occurrence of torpor appeared to be random and was not seen in all animals observed during the study.

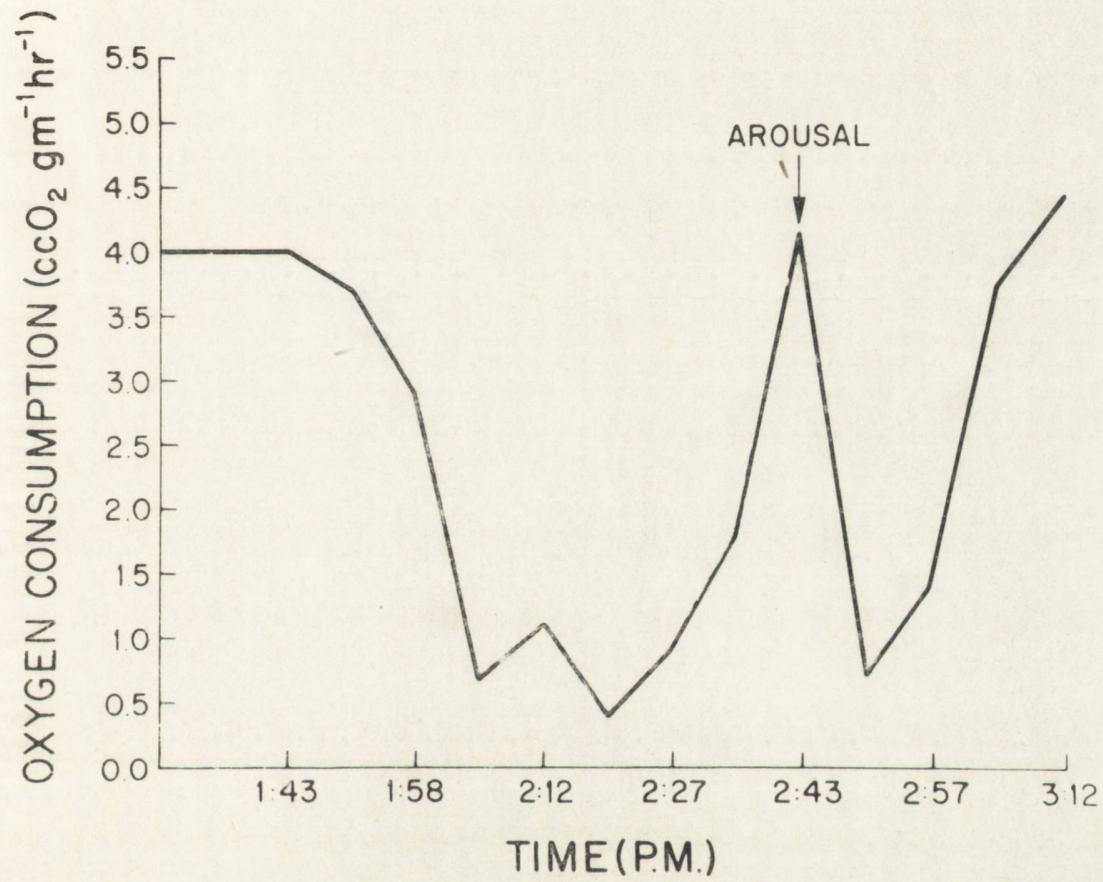

Fig. 1. Oxygen consumption of an individual shrew during a period of torpor-like behavior.

The observations of a torpor-like state in shrews has been reported in one other instance. G ę b c z y ń s k i (1971) observed an abrupt three fold reduction in the oxygen consumption of $S$. araneus during a fasting experiment. The animal was alive and did not respond to knocking and tilting of the chamber. Recovery, however, did occur.

Further studies are needed to determine the extent of daily torpor in shrews and its energetic significance.

Acknowledgements: This study was supported in part by NSF grants (NSFGB6392 and NSFGB-15916). Graphics and typing were done by Environmental Science and Engineering, Inc., Gainesville, Florida, U.S.A. 


\section{REFERENCES}

B a r tholomew G. A., 1972: Aspects of timing and periodicity of heterothermy. [In: F. E. South et al. (eds.). "Hibernation and Hypothermia, Perspectives and Challenges"]. Elsevier: 663-680. New York. G ę b c z yńs k i M., 1965: Seasonal and age changes in the metabolism and activity of Sorex araneus $\mathrm{L}$ in na e u s, 1758. Acta theriol., 10, 22: 303-331. G ę b c z yn s k i M., 1971: The rate of metabolism of the lesser shrew. Acta theriol., 16, 18: 329-339. V o g e l P., 1976: Energy consumption of European and African shrews. Acta theriol., 21, 14: 207-215.

Accepted, April 3, 1978. 